\title{
Caribou Distribution During the Post-Calving Period in Relation to Infrastructure in the Prudhoe Bay Oil Field, Alaska
}

\author{
MATTHEW A. CRONIN,,${ }^{1,2}$ STEVEN C. AMSTRUP,${ }^{3}$ GEORGE M. DURNER,${ }^{1,3}$ LYNN E. NOEL, ${ }^{1}$ \\ TRENT L. McDONALD ${ }^{4}$ and WARREN B. BALLARD ${ }^{1,5}$
}

(Received 4 October 1996; accepted in revised form 8 September 1997)

\begin{abstract}
There is concern that caribou (Rangifer tarandus) may avoid roads and facilities (i.e., infrastructure) in the Prudhoe Bay oil field (PBOF) in northern Alaska, and that this avoidance can have negative effects on the animals. We quantified the relationship between caribou distribution and PBOF infrastructure during the post-calving period (mid-June to mid-August) with aerial surveys from 1990 to 1995 . We conducted four to eight surveys per year with complete coverage of the PBOF. We identified active oil field infrastructure and used a geographic information system (GIS) to construct ten $1 \mathrm{~km}$ wide concentric intervals surrounding the infrastructure. We tested whether caribou distribution is related to distance from infrastructure with a chi-squared habitat utilization-availability analysis and log-linear regression. We considered bulls, calves, and total caribou of all sex/age classes separately. The habitat utilization-availability analysis indicated there was no consistent trend of attraction to or avoidance of infrastructure. Caribou frequently were more abundant than expected in the intervals close to infrastructure, and this trend was more pronounced for bulls and for total caribou of all sex/age classes than for calves. Log-linear regression (with Poisson error structure) of numbers of caribou and distance from infrastructure were also done, with and without combining data into the $1 \mathrm{~km}$ distance intervals. The analysis without intervals revealed no relationship between caribou distribution and distance from oil field infrastructure, or between caribou distribution and Julian date, year, or distance from the Beaufort Sea coast. The log-linear regression with caribou combined into distance intervals showed the density of bulls and total caribou of all sex/age classes declined with distance from infrastructure. Our results indicate that during the post-calving period: 1) caribou distribution is largely unrelated to distance from infrastructure; 2) caribou regularly use habitats in the PBOF; 3) caribou often occur close to infrastructure; and 4) caribou do not appear to avoid oil field infrastructure.
\end{abstract}

Key words: caribou, Rangifer tarandus, caribou distribution, oil field infrastructure, petroleum development

RÉSUMÉ. On s'inquiète du fait que le caribou (Rangifer tarandus) pourrait éviter les routes et installations (c-à-d. les infrastructures) du champ pétrolifère de Prudhoe Bay dans l'Alaska septentrional et que ce comportement pourrait avoir des répercussions négatives sur les animaux. Des relevés aériens effectués de 1990 à 1995 ont permis de quantifier le rapport entre la distribution du caribou et les infrastructures du champ pétrolifère de Prudhoe Bay au cours de la période suivant immédiatement la mise bas (de mi-juin à mi-août). On a procédé à un nombre de relevés annuels allant de quatre à huit, couvrant toute la superficie du champ. On a identifié les infrastructures du champ pétrolifère qui étaient en activité et utilisé un système d'information géographique (SIG) pour construire dix anneaux concentriques de $1 \mathrm{~km}$ de large entourant chaque infrastructure. On a testé l'hypothèse que la distribution du caribou est reliée à l'éloignement de l'infrastructure grâce au test de chi carré entre l'utilisation et la disponibilité de l'habitat, et à la régression log-linéaire. On a tenu compte séparément de la catégorie des mâles, de celle des veaux et de celle de la population totale, sexe et âge confondus. L'analyse de l'utilisation et de la disponibilité de l'habitat révélait qu'il n'y avait pas de schéma cohérent d'attrait ou d'évitement des infrastructures. Les caribous étaient souvent plus abondants que prévu dans les anneaux proches des infrastructures, et cette tendance était plus prononcée pour les mâles adultes et pour l'ensemble des catégories, sexe et âge confondus, que pour les veaux. On a aussi fait la régression log-linéaire (en incluant la structure d'erreur de Poisson) des nombres de caribous et des distances par rapport à l'infrastructure en regroupant et sans regrouper les données à l'intérieur des anneaux de $1 \mathrm{~km}$ de largeur. L'analyse sans regroupement montrait qu'il n'existe pas de rapport entre la distribution du caribou et l'éloignement des infrastructures du champ pétrolifère, ou entre la distribution du caribou et la date julienne ou même l'éloignement de la côte de la mer de Beaufort. La regression log-linéaire avec les caribous regroupés dans des anneaux concentriques montrait que la densité des mâles adultes et de l'ensemble de la population, sexe et âge confondus, était plus élevée dans les anneaux jouxtant les infrastructures. Nos résultats indiquent que, durant la période suivant immédiatement

\footnotetext{
${ }^{1}$ LGL Alaska Research Associates, Inc., 4175 Tudor Centre Drive, Suite 202, Anchorage, Alaska 99508, U.S.A.

${ }^{2}$ University of Alaska, School of Agriculture and Land Resources Management, Agriculture and Forestry Experiment Station, Fairbanks, Alaska 99775, U.S.A.

${ }^{3}$ Present address: Biological Resources Division, U.S. Geological Survey, 1011 East Tudor Road, Anchorage, Alaska 99503, U.S.A.

${ }^{4}$ Western Ecosystems Technology Inc., 2003 Center Ave., Cheyenne, Wyoming 82001, U.S.A.

${ }^{5}$ Present address: Department of Range, Wildlife, and Fisheries Management, Texas Tech University, Box 42125, Lubbock, Texas 79409, U.S.A.

(C) The Arctic Institute of North America
} 
la mise bas: (1) dans une large mesure, la distribution du caribou n'est pas reliée à l'éloignement des infrastructures; (2) le caribou utilise les habitats au sein du champ pétrolifère de Prudhoe Bay sur une base régulière; (3) le caribou se trouve fréquemment près des infrastructures; et (4) le caribou ne semble pas chercher à éviter les infrastructures du champ pétrolifère.

Mots clés: caribou, Rangifer tarandus, distribution du caribou, infrastructures du champ pétrolifère, exploitation pétrolière

Traduit pour la revue Arctic par Nésida Loyer.

\section{INTRODUCTION}

Caribou (Rangifer tarandus) of the Central Arctic Herd $(\mathrm{CAH})$ in Alaska occupy summer range on the coastal plain in northern Alaska. This range encompasses the Prudhoe Bay oil field (PBOF) and other adjacent oil fields. There has been concern that the oil fields may negatively affect caribou through habitat loss, disturbance, impedance of movements, and displacement to inferior foraging areas (Dau and Cameron, 1986; Cameron, 1992, 1994; Cameron et al., 1992, 1995; Nellemann and Cameron, 1996).

Impacts of the oil fields can be considered on two levels, impacts on individual animals and impacts on the herd as a whole (Bergerud et al., 1984; Cronin et al., 1994; Ballard and Cronin, 1995; Cronin et al., 1997, 1998). Opinions differ regarding the impacts at the herd level. Some researchers have suggested that herd productivity has been reduced because of oil field impacts (Cameron, 1992, 1994, 1995; Nellemann and Cameron, 1996). Others acknowledge the potential for herd-level impacts, but point out the difficulty of distinguishing human impacts from other environmental factors that affect caribou herds (Bergerud et al., 1984; Maki, 1992; Ballard and Cronin, 1995; Cronin et al., 1997, 1998). These authors note that the CAH has grown steadily, with demographics similar to those of adjacent herds, since the oil fields were developed. This indicates that few or no herdlevel impacts have been realized.

Oil field impacts on individual caribou of the CAH have been assessed through studies of distribution and movements in and around the oil fields. In one study, relatively low densities of cow and calf caribou (during the calving season) were observed within 1-2 km of an oil field road (Dau and Cameron, 1986; Cameron et al., 1992). These low densities were attributed to avoidance of the road by parturient cows, which are known to be sensitive to disturbance for a few weeks around calving time. Cameron et al. (1995) also reported fewer observations of caribou in the Prudhoe Bay area than in other areas across the Alaskan arctic coastal plain during the post-calving summer period. In contrast, six years (1990-95) of extensive aerial surveys in and around the PBOF during the post-calving period indicated frequent use of, and movements through, the PBOF (Pollard et al., 1996a).

Because of continued concerns over potential disturbance and displacement of caribou from the PBOF (Cameron, 1995; Cameron et al., 1995; Nellemann and Cameron, 1996), we assessed caribou distribution using the survey data collected between 1990 and 1995. In a previous paper, we described the numbers, distribution, and general movements of caribou during the post-calving period in the PBOF (Pollard et al., 1996a). In the present study, we tested whether the distribution and abundance of calves, bulls, and total caribou of all sex/age classes are influenced by oil field infrastructure. We tested the null hypothesis that the distribution of caribou is unrelated to distance from infrastructure during the postcalving period.

\section{STUDY AREA}

The PBOF survey area lies between $147^{\circ} 41^{\prime}$ and $149^{\circ} 00^{\prime}$ west longitude and extends south from the Beaufort Sea coast to $70^{\circ} 05^{\prime}$ north latitude (Fig. 1). Relief ranges from 0 to $23 \mathrm{~m}$ above sea level. The terrain has many shallow lakes and drained lake basins, and vegetation dominated by wet and moist tundra (Walker et al., 1980). The PBOF includes 53 producing oil well pads, 31 exploration drilling pads, 8 gathering centers, 2 gravel landing strips for jet aircraft, and 2 base camps, which serve as operation centers and housing for oil field personnel. All facilities are built on gravel pads (approximately $1.5 \mathrm{~m}$ in elevation) and are connected by a network of gravel roads (totaling approximately $220 \mathrm{~km}$ in length). Above-ground pipelines run adjacent to many of the roads. The PBOF survey area encompasses $1393 \mathrm{~km}^{2}$, including $179 \mathrm{~km}^{2}$ of freshwater ponds and lakes. Potential predators of caribou include grizzly bears (Ursus arctos), which are abundant in the Prudhoe Bay oil fields, and wolves (Canis lupus), which are rare in the area.

\section{METHODS}

We counted caribou on 37 surveys from fixed-wing aircraft (Cessna 206 and 207) flying at $130 \mathrm{~km} / \mathrm{hr}$ and $90 \mathrm{~m}$ above ground level with two observers and pilot. Each survey consisted of flights along 29 systematically spaced $(1.6 \mathrm{~km})$, fixed-width transects that ran north/south. The pilot used a Global Positioning System (GPS) receiver to navigate the aircraft, and observers searched for caribou within an $800 \mathrm{~m}$ wide swath on both sides of the transect centerline. We covered $100 \%$ of the study area on 34 of the 37 surveys and $50-95 \%$ of the study area on 3 surveys. Our observations consisted of the numbers, classification, and location of groups of caribou. Each observation was entered into a laptop computer that was linked to the GPS receiver in the airplane. The position of a group of caribou was defined as the central point of that group. This point was determined from GPS coordinates and a visual estimate of group position relative to the transect line. The aircraft circled large groups (of more 


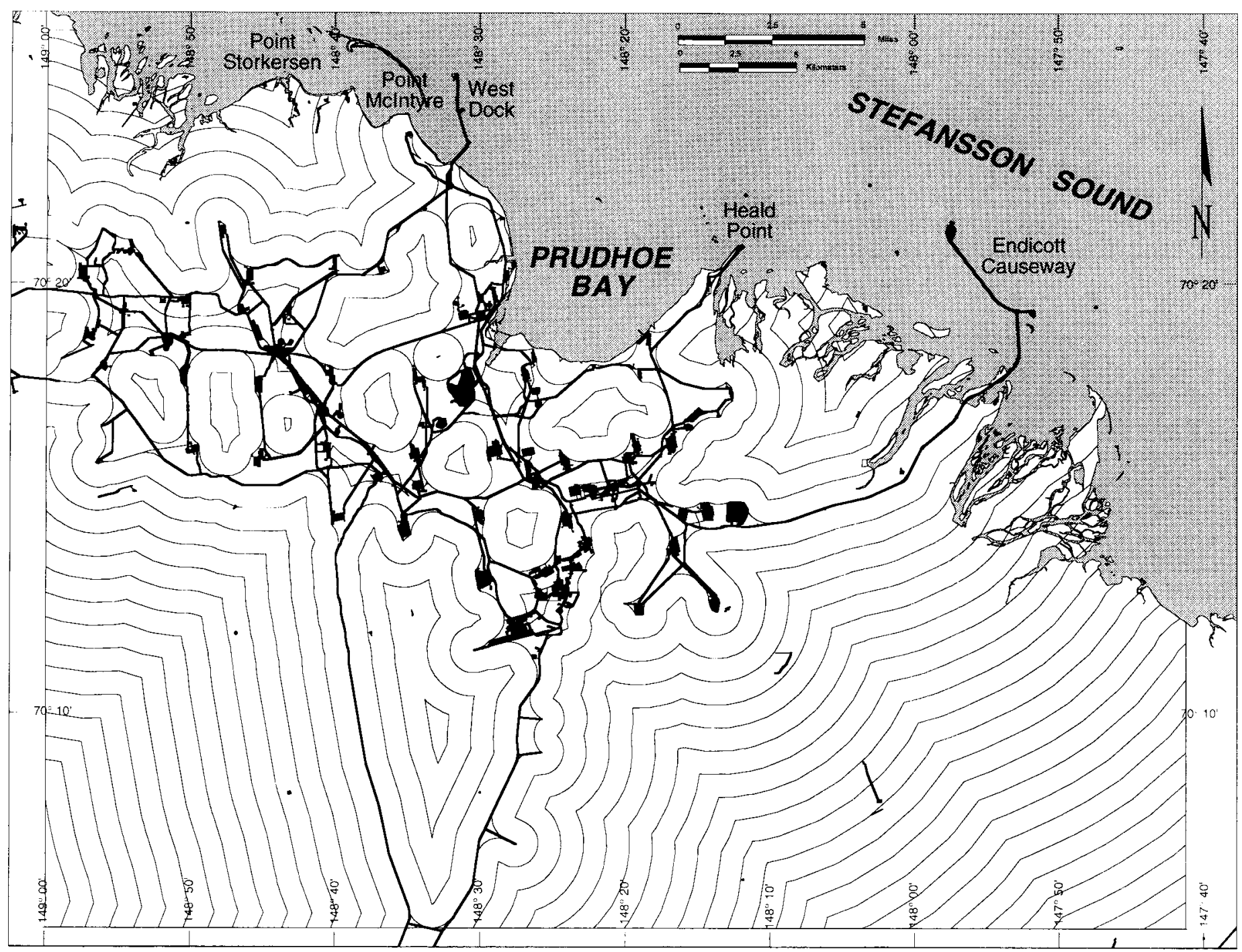

FIG. 1. The study area, showing distance intervals (1 km wide) surrounding active infrastructure (roads, gravel pads, pipelines, facilities) of the Prudhoe Bay oil field, Alaska.

than 100 animals) to facilitate counting and classification. During the surveys, calves and adult bulls were readily identifiable, but cows and young bulls, which are similar in size and appearance, were hard to differentiate. Therefore, we limited data analyses to groups of calves, adult bulls, and total caribou of all sex/age classes. Calf distribution can be considered indicative of the distribution of parturient females. Surveys were conducted between 0800 and 1700 Alaska Daylight Time, depending on weather conditions, from 20 June to 18 August each year. Calving by $\mathrm{CAH}$ caribou is usually completed by mid-June (Cameron et al., 1984; Smith and Cameron, 1990), so these survey dates were during the post-calving period.

We used Geographic Information System (GIS) ARC/ INFO $^{\circledR}$ software to generate a point coverage of caribou group locations. Distances of caribou groups from active oil field infrastructure were calculated with the NEAR command in ARC/INFO ${ }^{\circledR}$. Infrastructure was identified as all roads and facilities that were in active use for activities such as construction, drilling, and vehicular or pedestrian traffic.
Abandoned gravel pads that had no active operations and were not connected to other infrastructure by roads were not included. We assumed that caribou react similarly to different types of infrastructure (e.g., roads, drilling platforms) to which they might be exposed and did not further differentiate among types of infrastructure. We established concentric distance intervals surrounding oil field infrastructure. The intervals, $1 \mathrm{~km}$ wide as in previous studies (Dau and Cameron, 1986; Cameron et al., 1992), were generated with the BUFFER command in ARC/INFO ${ }^{\circledR}$ (Fig. 1). The area $\left(\mathrm{km}^{2}\right)$ of each distance interval was calculated, excluding the area of lakes and ponds identified on 1:63 360 scale maps.

Two analyses assessed caribou distribution in relation to oil field infrastructure. First, we compared the expected and observed numbers of caribou in each of the intervals $1-10 \mathrm{~km}$ from infrastructure with a habitat utilization-availability analysis using the methods of Neu et al. (1974). We used a Bonferroni $\mathrm{Z}$ statistic to calculate $95 \%$ confidence intervals around the observed proportion of caribou within each interval. The expected proportion of individuals was calculated by 
assuming that the total number of observed caribou was distributed homogeneously relative to the area of each interval (i.e., \# observed $\div$ area of interval). If the expected proportion was outside the observed $95 \%$ confidence interval, then the observed numbers were considered significantly lesser or greater than expected. As in Neu et al.'s (1974) example with moose (Alces alces), we did this analysis by combining all surveys into annual totals for each sex/age class. Utilization-availability analyses were performed using SAS (version 6.09, SAS Institute, Inc., Cary, North Carolina).

Second, we evaluated the distribution of caribou with loglinear regression models. Because caribou observations are counts rather than continuous measurements, normal theory regressions or ANOVAs are not appropriate analyses. Linear models can adequately address discrete distributions if counts are consistently large, and if they do not vary greatly among categories (Manly, 1994). Caribou counts, however, were highly variable with regard to distance from infrastructure, and the numbers of calves and bulls varied greatly within and among groups. Preliminary plots of the distributions and numbers of caribou of all classes suggested that assumptions of normality in the patterns of these data could not be justified. Log-linear models correctly handle non-normal count data and can assess effects of interactions among several independent variables (Manly, 1994).

Our models were of the form:

$$
Y=e^{\left(B_{0}+B_{1} X_{1}+B_{2} X_{2}+B_{3} X_{3}+\ldots . .+B_{p} X_{p}\right)},
$$

where $Y$, the number of caribou observed, is distributed Poisson, $e$ is the base of the natural logarithm, the $X$ values are the independent variables (i.e., the covariates), and $B_{i}$ are coefficients of the independent variables. We hypothesized that the distribution of caribou could be explained by 1) distance from infrastructure $\left.\left(X_{1}\right) ; 2\right)$ distance from the Beaufort Sea coast (which is thought to be important insect-relief habitat, Pollard et al., 1996a, b) $\left(X_{2}\right)$; 3$)$ year of the survey $\left(X_{3}\right)$; 4) Julian date of the survey $\left(X_{4}\right)$; and 5) pairwise interactions among these variables (e.g., $X_{5}=X_{1} \cdot X_{2}, X_{6}=X_{1} \cdot X_{3}$, $\left.X_{7}=X_{1} \cdot X_{4}\right)$. Interaction effects were modeled by the simple multiplication of the individual covariates (Manly et al., 1993; Manly, 1994). Log-linear models were built using the "Nonlin" command in SYSTAT V7.0 (SPSS Inc., Chicago, Illinois). The null hypothesis was that the distribution of caribou was unrelated to the covariates. Separate models were built with total caribou, calves, and bulls as the Y (i.e., dependent) variable.

We constructed full models incorporating all of the covariates plus interactions, and used backward stepping (Neter et al., 1990) to progressively eliminate variables in search of the model that best fit the observations. Model fit was evaluated by Akaike's Information Criterion (AIC) (Akaike, 1973). The AIC is defined as "negative 2 times the log-likelihood plus 2 times the model degrees of freedom $[-2 \cdot \ln (\mathrm{L})+2 \cdot($ model df)]" (Akaike, 1973; LeBreton et al., 1992). Like the adjusted $R^{2}$ in normal theory regression, the AIC balances improvement in fit achieved by adding terms to the model against the cost of increasing the model degrees of freedom (LeBreton et al., 1992). Model selection by AIC is functionally equivalent to selection by drop in deviance chisquared (LeBreton et al., 1992; Manly et al., 1993; Manly, 1994). A large AIC value indicates a large difference between the fitted and the observed values of $\mathrm{Y}$ and shows that the covariates (or X variables) in the model do not explain the variation in the data very well. Conversely, a small AIC value suggests that the covariates $d o$ explain much of the variation in the observed Y values. The models with the lowest AIC values were judged to be those with the best fits (Akaike, 1973). Although our data were distributed in a fashion similar to a Poisson distribution, variances were larger than in a Poisson distribution. Hence, we adjusted for extraneous variance by multiplying the calculated variances by the ratio of the log-likelihood chi-squared values to the error degrees of freedom (Manly, 1994).

We first applied the log-linear models using the numbers and exact location (latitude/longitude) of each observed group of caribou as the $\mathrm{Y}$ variables. Because there was extensive variation in numbers of caribou in groups, we also combined caribou observations within the $1 \mathrm{~km}$ wide distance intervals used in the habitat utilization-availability analysis. In this approach, we built log-linear models in which Y was the density of caribou (again, separate models were built for each of the three classes of caribou) in each interval, and X was the distance $(1-10 \mathrm{~km})$ of each interval from the infrastructure. When data were combined within distance intervals, much of the inherent variation was hidden. This dramatically reduced the AIC values and appeared to improve the model fits. This analysis was limited to caribou density relative to infrastructure, and did not include distance from the coast, Julian date, or year.

Coefficients $\left(B_{i}\right)$ were considered different from zero at the $5 \%$ level of significance (i.e., the regression relationship explained a significant proportion of the variation in the observations) if the ratio of $B$ to its standard error (T-ratio) exceeded I2.0I (Manly et al., 1993; Manly, 1994).

\section{RESULTS}

Between 1990 and 1995, we conducted 37 surveys of the PBOF during the post-calving period. We saw a total of 77833 caribou, of which 75639 were within the first ten $1 \mathrm{~km}$ intervals (i.e., within $10 \mathrm{~km}$ of infrastructure). The remaining 2194 caribou were more than $10 \mathrm{~km}$ from infrastructure. We observed 24120 bulls, 17009 calves, and 34510 caribou of other sex/age classes within $10 \mathrm{~km}$ of infrastructure. These numbers of caribou, observed during multiple surveys over six years, probably include many resightings of the same animals, and do not reflect the herd size for any given time. See Cronin et al. $(1997,1998)$ for population-level analyses of the CAH. The complete data for each aerial survey, including the numbers of caribou, weather conditions, levels of insect activity, and caribou movements are described by Pollard et al. (1996a) and in unpublished reports (Cronin et 
TABLE 1. Numbers of caribou (calves, bulls, total caribou) observed during aerial surveys of the Prudhoe Bay oil field 1990-95. Observations are grouped into $1 \mathrm{~km}$ distance intervals from oil field structure.

\begin{tabular}{|c|c|c|c|c|c|c|c|c|c|c|c|c|c|}
\hline & \multicolumn{10}{|c|}{ Distance Interval } & \multicolumn{3}{|c|}{ Interval Totals } \\
\hline & 1 & 2 & 3 & 4 & 5 & 6 & 7 & 8 & 9 & 10 & $1-10$ & $11-23$ & $1-23$ \\
\hline Area $\left(\mathrm{km}^{2}\right)$ & 385.2 & 145.9 & 100.1 & 78.8 & 68.1 & 54.4 & 47.2 & 43.0 & 36.2 & 33.4 & 992.4 & 192.6 & 1185.0 \\
\hline \multicolumn{14}{|l|}{ Calves } \\
\hline 1990 & 175 & 16 & 226 & 529 & 9 & 2101 & 5 & 3 & 1 & 2 & 3067 & 0 & 3067 \\
\hline 1991 & 1286 & 21 & 427 & 99 & 15 & 104 & 12 & 14 & 8 & 15 & 2001 & 139 & 2140 \\
\hline 1992 & 3019 & 2263 & 125 & 611 & 220 & 1082 & 21 & 651 & 42 & 241 & 8275 & 192 & 8467 \\
\hline 1993 & 1333 & 86 & 12 & 239 & 10 & 25 & 18 & 0 & 4 & 1 & 1728 & 1 & 1729 \\
\hline 1994 & 401 & 96 & 31 & 22 & 30 & 146 & 52 & 74 & 119 & 59 & 1030 & 33 & 1063 \\
\hline 1995 & 272 & 91 & 10 & 10 & 60 & 64 & 110 & 290 & 1 & 0 & 908 & 0 & 908 \\
\hline Subtotal & 6486 & 2573 & 831 & 1510 & 344 & 3522 & 218 & 1032 & 175 & 318 & 17009 & 365 & 17374 \\
\hline \multicolumn{14}{|l|}{ Bulls } \\
\hline 1990 & 450 & 107 & 327 & 1039 & 10 & 1756 & 54 & 13 & 2 & 18 & 3776 & 20 & 3796 \\
\hline 1991 & 2104 & 142 & 512 & 213 & 191 & 159 & 88 & 58 & 34 & 26 & 3527 & 193 & 3720 \\
\hline 1992 & 4961 & 2928 & 186 & 396 & 225 & 1060 & 91 & 558 & 16 & 196 & 10617 & 257 & 10874 \\
\hline 1993 & 2343 & 438 & 269 & 496 & 59 & 85 & 115 & 175 & 103 & 2 & 4085 & 25 & 4110 \\
\hline 1994 & 684 & 238 & 80 & 32 & 53 & 66 & 51 & 30 & 36 & 24 & 1294 & 25 & 1319 \\
\hline 1995 & 241 & 316 & 6 & 5 & 101 & 7 & 65 & 80 & 0 & 0 & 821 & 0 & 821 \\
\hline Subtotal & 10783 & 4169 & 1380 & 2181 & 639 & 3133 & 464 & 914 & 191 & 266 & 24120 & 520 & 24640 \\
\hline \multicolumn{14}{|c|}{ Total Caribou } \\
\hline 1990 & 1076 & 158 & 1043 & 2511 & 47 & 7066 & 79 & 27 & 8 & 23 & 12038 & 34 & 12072 \\
\hline 1991 & 5844 & 281 & 1521 & 527 & 432 & 551 & 189 & 150 & 99 & 101 & 9695 & 1158 & 10853 \\
\hline 1992 & 14684 & 9408 & 586 & 2004 & 908 & 4328 & 175 & 2407 & 128 & 886 & 35514 & 845 & 36359 \\
\hline 1993 & 7156 & 775 & 416 & 1321 & 95 & 163 & 179 & 190 & 128 & 5 & 10428 & 33 & 10461 \\
\hline 1994 & 1825 & 801 & 175 & 122 & 149 & 415 & 208 & 225 & 342 & 173 & 4435 & 119 & 4554 \\
\hline 1995 & 1299 & 568 & 57 & 67 & 285 & 199 & 336 & 715 & 3 & 0 & 3529 & 5 & 3534 \\
\hline Total & 31884 & 11991 & 3798 & 6552 & 1916 & 12722 & 1166 & 3714 & 708 & 1188 & 75639 & 2194 & 77833 \\
\hline
\end{tabular}

al., 1996; Pollard et al., 1992a, b, 1996a, b; Pollard and Ballard, 1993; Pollard and Noel, 1994, 1995, 1996) which are available from the authors.

The area of each $1 \mathrm{~km}$ interval decreased with increasing distance from infrastructure (Table 1, Fig. 1). For example, the interval immediately adjacent to infrastructure (interval 1) was $385 \mathrm{~km}^{2}$, while the interval farthest from infrastructure (interval 23) was only $0.819 \mathrm{~km}^{2}$. In addition to having relatively small areas, the intervals beyond $10 \mathrm{~km}$ may be beyond the range where visual and auditory stimuli could be detected or at least beyond the range where important responses might be expected. Hence, we focused our analysis on the first ten $1 \mathrm{~km}$ intervals. Previous studies during the calving period (Dau and Cameron, 1986; Cameron et al., 1992) evaluated caribou distribution within the first six $1 \mathrm{~km}$ intervals from oil field infrastructure.

To provide a view of the actual data, the numbers of caribou observed each year within each $1 \mathrm{~km}$ distance interval are shown in Table 1, and the total numbers for all six years are plotted in Figure 2. Each point in Figure 2 represents an observed group of caribou. Visual examination of Figure 2 suggests that most groups contained fewer than 10 caribou, and that more caribou were observed within the two intervals closest to infrastructure than in the intervals $3-10 \mathrm{~km}$ from infrastructure. However, the data show considerable variation, which we assessed with the habitat availability-utilization and log-linear regression analyses.

\section{Habitat Availability-Utilization Analysis}

The habitat utilization-availability analysis showed distributions that varied among the six years and three caribou classes (Table 2). Bulls frequently occurred more than expected within the first two intervals: in the first interval in four years, and in the second interval in three years. The other intervals had more bulls than expected in zero, one, or two years. Total caribou of all sex/age classes also occurred more than expected in the first interval in four years, in the sixth interval in three years, and in the other intervals in zero, one, or two years. More calves than expected occurred in the first interval in two years, and in the sixth and eighth intervals in three years. Fewer calves than expected occurred in the first interval in three years, and in the second, third, fifth, and ninth intervals in five years. No consistent trend was found of avoidance of (or attraction to) infrastructure, except that possibly bulls and total caribou prefer locations near infrastructure. Overall, however, the availability-utilization analyses did not suggest rejection of our null hypothesis that distribution is unrelated to distance from infrastructure.

\section{Log-linear Regression Analyses}

Log-linear modeling of the distribution of caribou groups (without combining data into distance intervals) showed no significant relationships between the distribution of caribou and distance from infrastructure or other covariates. The AIC values were very large, and the T-ratios were all 


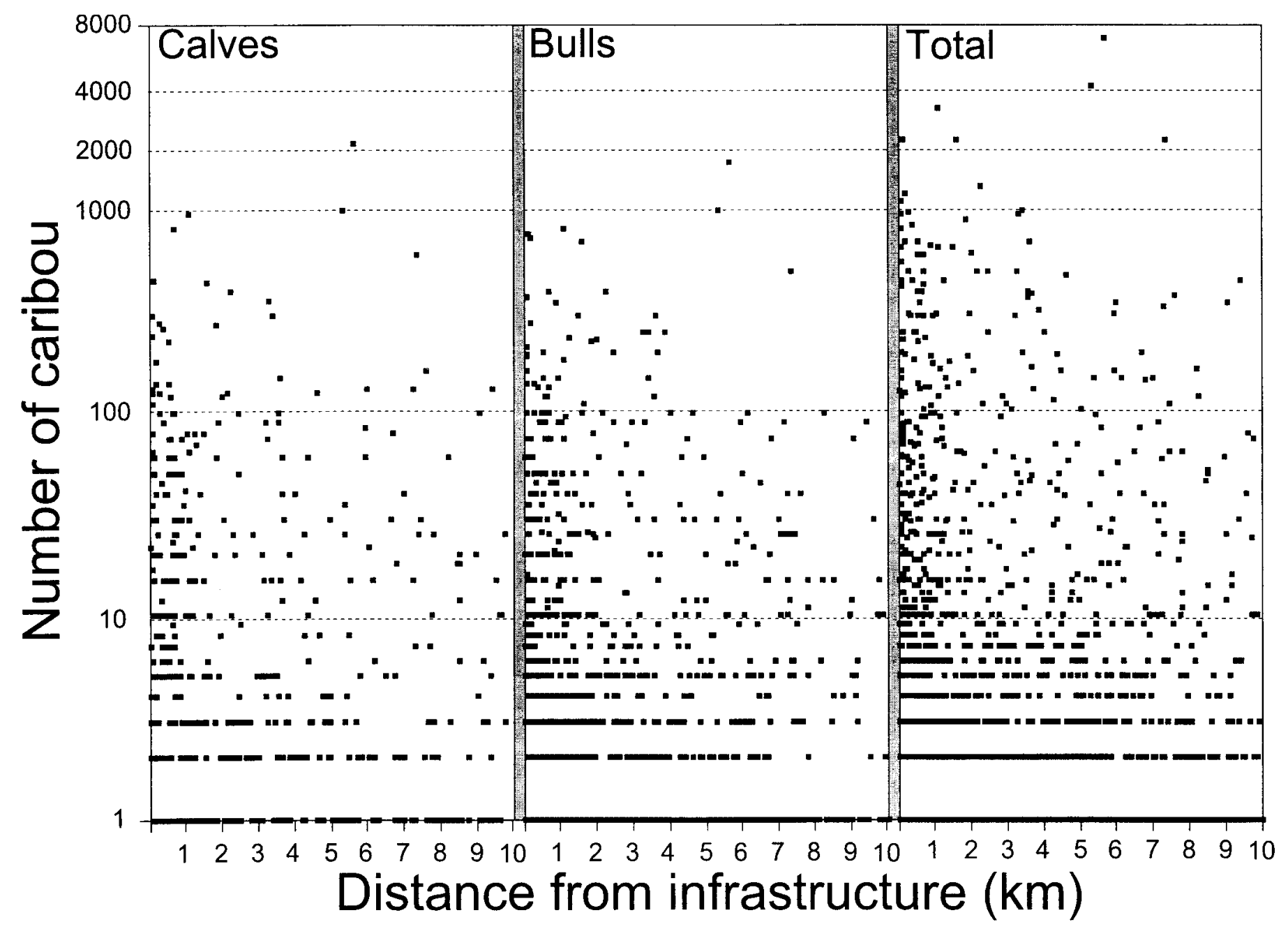

FIG. 2. Numbers of caribou (calves, bulls, and total caribou) plotted (log scale) against distance from Prudhoe Bay oil field infrastructure.

TABLE 2. Results of utilization - availability analysis for caribou distribution in ten $1 \mathrm{~km}$ intervals from oil field infrastructure for 6 years, 1990-95. The letters in the body of the table indicate whether the number of caribou observed in a given interval is significantly greater than $(\mathrm{G})$, less than $(\mathrm{L})$, or not significantly different from $(\mathrm{N})$ that expected for a given year.

\begin{tabular}{|c|c|c|c|c|c|c|c|c|c|c|c|c|c|c|c|c|c|c|c|c|c|}
\hline \multirow[b]{2}{*}{ Interval } & \multicolumn{7}{|c|}{ Bulls } & \multicolumn{7}{|c|}{ Calves } & \multicolumn{7}{|c|}{ Total Caribou of all Sex/age Classes } \\
\hline & 90 & '91 & '92 & '93 & 94 & '95 & \#G & 90 & '91 & '92 & '93 & '94 & '95 & \#G & 90 & '91 & '92 & '93 & '94 & '95 & $\# \mathrm{G}$ \\
\hline 1 & $\mathrm{~L}$ & $\mathrm{G}$ & $\mathrm{G}$ & G & $\mathrm{G}$ & $\mathrm{L}$ & 4 & $\mathrm{~L}$ & $\mathrm{G}$ & $\mathrm{L}$ & G & $\mathrm{N}$ & $\mathrm{L}$ & 2 & $\mathrm{~L}$ & $\mathrm{G}$ & $\mathrm{G}$ & $\mathrm{G}$ & $\mathrm{G}$ & $\mathrm{N}$ & 4 \\
\hline 2 & $\mathrm{~L}$ & $\mathrm{~L}$ & $\mathrm{G}$ & $\mathrm{L}$ & $\mathrm{G}$ & $\mathrm{G}$ & 3 & $\mathrm{~L}$ & $\mathrm{~L}$ & $\mathrm{G}$ & $\mathrm{L}$ & $\mathrm{L}$ & $\mathrm{L}$ & 1 & $\mathrm{~L}$ & $\mathrm{~L}$ & $\mathrm{G}$ & $\mathrm{L}$ & $\mathrm{G}$ & $\mathrm{N}$ & 2 \\
\hline 3 & $\mathrm{~L}$ & $\mathrm{G}$ & $\mathrm{L}$ & $\mathrm{L}$ & $\mathrm{L}$ & $\mathrm{L}$ & 1 & $\mathrm{~L}$ & $\mathrm{G}$ & $\mathrm{L}$ & $\mathrm{L}$ & $\mathrm{L}$ & $\mathrm{L}$ & 1 & $\mathrm{~L}$ & $\mathrm{G}$ & $\mathrm{L}$ & $\mathrm{L}$ & $\mathrm{L}$ & $\mathrm{L}$ & 1 \\
\hline 4 & $\mathrm{G}$ & $\mathrm{L}$ & $\mathrm{L}$ & $\mathrm{G}$ & $\mathrm{L}$ & $\mathrm{L}$ & 2 & $\mathrm{G}$ & $\mathrm{L}$ & $\mathrm{N}$ & $\mathrm{G}$ & $\mathrm{L}$ & $\mathrm{L}$ & 2 & $\mathrm{G}$ & $\mathrm{L}$ & $\mathrm{L}$ & $\mathrm{G}$ & $\mathrm{L}$ & $\mathrm{L}$ & 2 \\
\hline 5 & $\mathrm{~L}$ & $\mathrm{~L}$ & $\mathrm{~L}$ & $\mathrm{~L}$ & $\mathrm{~L}$ & $\mathrm{G}$ & 1 & $\mathrm{~L}$ & $\mathrm{~L}$ & $\mathrm{~L}$ & $\mathrm{~L}$ & $\mathrm{~L}$ & $\mathrm{~N}$ & 0 & $\mathrm{~L}$ & $\mathrm{~L}$ & $\mathrm{~L}$ & $\mathrm{~L}$ & $\mathrm{~L}$ & $\mathrm{~N}$ & 0 \\
\hline 6 & $\mathrm{G}$ & $\mathrm{N}$ & $\mathrm{G}$ & $\mathrm{L}$ & $\mathrm{N}$ & $\mathrm{L}$ & 2 & $\mathrm{G}$ & $\mathrm{N}$ & $\mathrm{G}$ & $\mathrm{L}$ & $\mathrm{G}$ & $\mathrm{N}$ & 3 & $\mathrm{G}$ & $\mathrm{N}$ & $\mathrm{G}$ & $\mathrm{L}$ & $\mathrm{G}$ & $\mathrm{N}$ & 3 \\
\hline 7 & $\mathrm{~L}$ & $\mathrm{~L}$ & $\mathrm{~L}$ & $\mathrm{~L}$ & $\mathrm{~N}$ & $\mathrm{G}$ & 1 & $\mathrm{~L}$ & $\mathrm{~L}$ & $\mathrm{~L}$ & $\mathrm{~L}$ & $\mathrm{~N}$ & $\mathrm{G}$ & 1 & $\mathrm{~L}$ & $\mathrm{~L}$ & $\mathrm{~L}$ & $\mathrm{~L}$ & $\mathrm{~N}$ & $\mathrm{G}$ & 1 \\
\hline 8 & $\mathrm{~L}$ & $\mathrm{~L}$ & $\mathrm{G}$ & $\mathrm{N}$ & $\mathrm{L}$ & $\mathrm{G}$ & 2 & $\mathrm{~L}$ & $\mathrm{~L}$ & $\mathrm{G}$ & $\mathrm{L}$ & $\mathrm{G}$ & $\mathrm{G}$ & 3 & $\mathrm{~L}$ & $\mathrm{~L}$ & $\mathrm{G}$ & $\mathrm{L}$ & $\mathrm{N}$ & $\mathrm{G}$ & 2 \\
\hline 9 & $\mathrm{~L}$ & $\mathrm{~L}$ & $\mathrm{~L}$ & $\mathrm{~L}$ & $\mathrm{~N}$ & $\mathrm{~L}$ & 0 & $\mathrm{~L}$ & $\mathrm{~L}$ & $\mathrm{~L}$ & $\mathrm{~L}$ & $\mathrm{G}$ & $\mathrm{L}$ & 1 & $\mathrm{~L}$ & $\mathrm{~L}$ & $\mathrm{~L}$ & $\mathrm{~L}$ & $\mathrm{G}$ & $\mathrm{L}$ & 1 \\
\hline 10 & $\mathrm{~L}$ & $\mathrm{~L}$ & $\mathrm{~L}$ & $\mathrm{~L}$ & $\mathrm{~L}$ & $\mathrm{~L}$ & 0 & $\mathrm{~L}$ & $\mathrm{~L}$ & $\mathrm{~N}$ & $\mathrm{~L}$ & $\mathrm{G}$ & $\mathrm{L}$ & 1 & $\mathrm{~L}$ & $\mathrm{~L}$ & $\mathrm{~L}$ & $\mathrm{~L}$ & $\mathrm{~N}$ & $\mathrm{~L}$ & 0 \\
\hline
\end{tabular}

nonsignificant (i.e., < |2.0|; Table 3). The ranges of AIC values for all of the models (using all or some of the covariates) were 96386 to 108065 for calves, 107425 to 118846 for bulls, and 358797 to 399209 for total caribou. The T-ratios were less than 0.570 for calves, less than 0.390 for bulls, and less than 0.500 for total caribou. That is, none of the log-linear regressions showed a significant relationship between caribou distribution and distance from infrastructure, distance from the coast, Julian date, year, or any pairwise combination of these covariates.

Because the AIC is derived from the log-likelihood chisquares, which measure the difference between observed values and corresponding fitted values (Akaike, 1973; LeBreton et al., 1992; Manly, et al., 1993; Manly, 1994), small AIC values result when values predicted by the model are close to the values observed in the data. Large AIC values, 
TABLE 3. Results of log-linear regression modeling for total caribou, bulls, and calves $(\mathrm{Y})$ with independent variables $\left(\mathrm{X}_{\mathrm{i}}\right)$ : distance from infrastructure; distance from coast; distance from infrastructure and coast; and their interactions.

\begin{tabular}{|c|c|c|c|c|c|}
\hline & $X_{\mathrm{i}}$ & $\beta$ & SE & T-Ratio & AIC \\
\hline \multicolumn{6}{|l|}{$\mathrm{Y}=\mathrm{TOTAL}$ CARIBOU } \\
\hline \multirow[t]{2}{*}{ Distance from infrastructure } & Intercept & 3.560 & 2.209 & & 399165 \\
\hline & $\mathrm{X}_{\mathrm{i}}$ & 0.009 & 0.596 & 0.015 & \\
\hline \multirow[t]{2}{*}{ Distance from coast } & Intercept & 4.044 & 2.127 & & 383996 \\
\hline & $X_{i}$ & -0.072 & 0.279 & -0.256 & \\
\hline \multirow[t]{4}{*}{ Distance from infrastructure and coast } & Intercept & 3.735 & 2.334 & & 380773 \\
\hline & $\mathrm{X}_{\mathrm{i}}$ & 0.103 & 0.578 & 0.178 & \\
\hline & $\mathrm{X}_{2}$ & -0.033 & 0.301 & -0.108 & \\
\hline & $\mathrm{X}_{\text {interaction }}$ & -0.012 & 0.076 & -0.156 & \\
\hline \multicolumn{6}{|l|}{$\mathrm{Y}=\mathrm{BULLS}$} \\
\hline \multirow[t]{2}{*}{ Distance from infrastructure } & Intercept & 2.502 & 2.083 & & 118731 \\
\hline & $X_{i}$ & -0.027 & 0.607 & -0.044 & \\
\hline \multirow[t]{2}{*}{ Distance from coast } & Intercept & 2.797 & 2.118 & & 116020 \\
\hline & $\mathrm{X}_{\mathrm{i}}$ & -0.052 & 0.252 & -0.207 & \\
\hline \multirow[t]{4}{*}{ Distance from infrastructure and coast } & Intercept & 2.527 & 2.269 & & 114763 \\
\hline & $\mathrm{X}_{\mathrm{i}}$ & 0.085 & 0.590 & 0.144 & \\
\hline & $\mathrm{X}_{2}$ & -0.007 & 0.270 & -0.026 & \\
\hline & $\mathrm{X}_{\text {interaction }}$ & -0.015 & 0.074 & -0.196 & \\
\hline \multicolumn{6}{|l|}{$\mathrm{Y}=\mathrm{CALVES}$} \\
\hline \multirow[t]{2}{*}{ Distance from infrastructure } & Intercept & 1.975 & 2.487 & & 107805 \\
\hline & $\mathrm{X}_{\mathrm{i}}$ & 0.044 & 0.624 & 0.071 & \\
\hline \multirow{2}{*}{ Distance from coast } & Intercept & 2.656 & 2.272 & & 102793 \\
\hline & $X_{i}$ & -0.094 & 0.334 & -0.281 & \\
\hline \multirow{4}{*}{ Distance from infrastructure and coast } & Intercept & 2.316 & 2.549 & & 101855 \\
\hline & $X_{\mathrm{i}}$ & 0.117 & 0.603 & 0.194 & \\
\hline & $\mathrm{X}_{2}$ & -0.065 & 0.362 & -0.178 & \\
\hline & $\mathrm{X}_{\text {interaction }}$ & -0.008 & 0.083 & -0.097 & \\
\hline
\end{tabular}

on the other hand, occur when the average difference between the actual and fitted values is large. With 2103 groups observed, the average AIC per observation for total caribou was 171 - 190 (e.g., 358 797/2103 to 399 209/2103). Values this large indicated very poor fits of all of our models. In fact, the variation in AIC values (and hence the log-likelihood chisquared) among models built for each category of caribou was grossly overshadowed by the magnitude of all of the AIC values. Hence, choosing the best model according to AIC values was meaningless. As would be expected with models that fit so poorly, none of the calculated regression parameters were significantly different from zero. Table 3 summarizes the AIC and regression parameters for the models, including the covariates of primary interest (distance from infrastructure, distance from the coast, and both of these covariates together). The log-linear analysis indicates we cannot reject the null hypothesis that caribou distribution is unrelated to distance from oil field infrastructure.

When we combined caribou observations into $1 \mathrm{~km}$ distance intervals, the log-linear regression analyses resulted in better fits of the models to the data than did the analyses with the non-combined data. This better fit is indicated by lower AIC values and higher T-ratios (Table 4). The T-ratios for bulls and total caribou were significant $(>|2.0|$ ) and the negative signs indicate that the relationship is decreasing density of caribou with increasing distance from infrastructure. Thus, densities of bulls and total caribou were higher in the distance intervals close to infrastructure, a trend also seen in the availability-utilization analysis. For calves, the slope was in the same direction (i.e., negative), but nonsignificant. The log-linear analysis with data combined into distance intervals allows rejection of the null hypothesis that caribou distribution is unrelated to distance from infrastructure for bulls and total caribou. These groups tend to occur close to infrastructure.

In summary, the log-linear analyses, without combining data into intervals, indicate that caribou distribution in the PBOF is unrelated to the covariates (distance from infrastructure, distance from the coast, Julian data, year). The log-linear analyses of the caribou in distance intervals suggest that caribou prefer habitats near infrastructure to those farther away. Our analyses suggest that caribou, rather than avoiding oil field infrastructure, occur independent of, or close to, infrastructure. Our analyses also indicate that caribou distribution was unrelated to distance from the coast, interactions between the distance from the coast and the distance from infrastructure, Julian date, and year of the survey.

\section{DISCUSSION}

Our results indicate that during the post-calving period, caribou are abundant in the PBOF; they often occur close to oil field infrastructure; and their overall distribution is largely unrelated to the distribution of infrastructure. Conversely, Cameron et al. (1995) reported that caribou avoided the general area encompassing the PBOF during the post-calving period. Timing and methodology may account for these differing observations. Cameron et al. (1995) reported data for 141 radio-collared caribou (6-40/year), each of which was relocated at least once per year during the period 25 June to 10 August. Our conclusions are based on over 75000 caribou 
TABLE 4. Results of log-linear regressions of densities of total caribou, bulls, and calves, combined into $1 \mathrm{~km}$ intervals with one independent variable, distance from oil field infrastructure.

\begin{tabular}{lcrccc}
\hline \hline $\mathrm{Y}_{\mathrm{i}}$ & $\mathrm{X}_{\mathrm{i}}$ & \multicolumn{1}{c}{$\beta_{i}$} & $\mathrm{SE}$ & T-Ratio & \multirow{2}{*}{ AIC } \\
\hline Total Caribou & Intercept & 0.9241 & 0.0765 & & \\
& $\mathrm{X}_{\mathrm{i}}$ & -0.0504 & 0.0131 & $-3.8406^{*}$ & 2862 \\
Bulls & Intercept & -0.1011 & 0.1358 & & \\
& $\mathrm{X}_{1}$ & -0.0914 & 0.0246 & $-3.7207^{*}$ & 715 \\
Calves & Intercept & 0.6360 & 0.1595 & & \\
& $\mathrm{X}_{1}$ & -0.0212 & 0.0264 & -0.8025 & 726 \\
\hline \hline
\end{tabular}

* Significant at the 0.05 level.

observations recorded during 37 aerial surveys of the entire PBOF. Surveys were distributed between 20 June and 18 August for each of six consecutive years. Our frequent surveys with complete coverage of the PBOF detected caribou use of, and movement through, the PBOF that the relatively infrequent radio-tracking surveys of Cameron et al. (1995) may have missed.

The analyses with data combined into distance intervals (log-linear and availability-utilization) suggested that caribou do not avoid oil field infrastructure, but occur close to it during the post-calving period. This result may reflect the frequent use of oil field infrastructure for relief from parasitic insects (Pollard et al., 1996b), but it also could be an artifact of the use of combined data. Combining individual observations into distance intervals is intuitively satisfying because it results in fewer data records, and it is convenient to think of zonal distances from infrastructure. However, combining observations into distance intervals dramatically reduces the variation in the data and could suggest distinct trends when the actual data show highly variable distributions. Indeed, whereas our analyses of the raw data suggested no trends (Table 3), analyses of data combined into distance intervals suggested caribou were attracted to infrastructure (Tables 2 and 4). Both alternatives (i.e., no relationship or attraction to infrastructure) are plausible, but the smoothing effect of combining data into intervals suggests the need for careful interpretation of results based upon combined data (e.g., Tables 2 and 4; Dau and Cameron, 1986; Cameron et al., 1992).

Our long-term monitoring demonstrates that caribou frequently use habitats in the PBOF and do not avoid oil field infrastructure during the post-calving period. Tolerance of oil field activity was also described for elk (Cervus elaphus), which simply shifted among areas, but did not abandon the range in which the oil field activity occurred (Van Dyke and Klein, 1996). It appears that with the proper mitigation actions, caribou can coexist with active oil field operations.

\section{ACKNOWLEDGEMENTS}

This study was funded by BP Exploration (Alaska) Inc. and LGL Alaska Research Associates, Inc. We would like to thank Dr. Chris Herlugson, Steve Taylor, Dr. Benny Gallaway, Dr. Steve Johnson, and Michelle Gilders for their ideas and support; Layne Adams and
Ron Skoog for useful comments on the manuscript; and Audrey Bishop for manuscript preparation.

\section{REFERENCES}

AKAIKE, H. 1973. Information theory and an extension of the maximum likelihood principle. In: Petran, B.N., and Csaki, F., eds. International Symposium on Information Theory. 2nd ed. Budapest, Hungary: Akademiai Kiadi. 267-281.

BALLARD, W.B., and CRONIN, M.A. 1995. Arctic Alaska caribou herds in relation to oil field development. In: Foster, S.Q., Pas, S., Rush, S., and Thorne, O., II, eds. Issues and technology in the management of impacted wildlife. Proceedings of the Sixth Symposium, Glenwood Springs, Colorado, 6-8 April 1994. Boulder, Colorado: Thorne Ecological Institute. 35-46.

BERGERUD, A.T., JAKIMCHUK, R.D., and CARRUTHERS, D.R. 1984. The buffalo of the North:Caribou (Rangifer tarandus) and human developments. Arctic 37:7-22.

CAMERON, R.D. 1992. Distribution and productivity of the Central Arctic caribou herd in relation to petroleum development: Case history studies with a nutritional perspective. Federal Aid in Wildlife Restoration, Progress Report, Project W-23-4, Study 3.35. Juneau, Alaska: Alaska Department of Fish and Game.

- 1994. Distribution and productivity of the Central Arctic caribou herd in relation to petroleum development: Case history studies with a nutritional perspective. Federal Aid in Wildlife Restoration, Progress Report, Projects W-23-1 to W-23-5, W24-1 to W-24-3, Study 3.35. Juneau, Alaska: Alaska Department of Fish and Game.

- 1995. Can petroleum development depress the productivity of Arctic caribou? In: Abstracts of the Second International Arctic Ungulate Conference, 13-17 August 1995, University of Alaska Fairbanks. 36.

CAMERON, R.D., WHITTEN, K.R., and SMITH, W.T. 1984. Development and alteration of caribou movement patterns. Federal Aid in Wildlife Restoration, Progress Report, Projects W-22-2, Job 3.29R. Juneau, Alaska: Alaska Department of Fish and Game.

CAMERON, R.D., REED, D.J., DAU, J.R., and SMITH, W.T. 1992. Redistribution of calving caribou in response to oil field development on the Arctic Slope of Alaska. Arctic 45:338-342.

CAMERON, R.D., LENART, E.A., REED, D.J., WHITTEN, K.R., and SMITH, W.T. 1995. Abundance and movements of caribou in the oilfield complex near Prudhoe Bay, Alaska. Rangifer 15:3-7.

CRONIN, M.A., BALLARD, W.B., TRUETT, J., and POLLARD, R.H. 1994. Mitigation of the effects of oil field development and transportation corridors on caribou. Final report prepared by LGL Alaska Research Associates, Inc., for Alaska Oil and Gas Association, 121 West Fireweed Lane, Suite 207, Anchorage, Alaska 99503. 24 p. + appendices.

CRONIN, M.A., DURNER, G., BRYAN, J., NOEL, L.E., and PIERSON, B.J. 1996. Caribou distribution relative to oil field infrastructure in the Prudhoe Bay oil field, Alaska. Final report prepared by LGL Alaska Research Associates, Inc., for BP 
Exploration (Alaska) Inc., P.O. Box 196612, Anchorage, Alaska 99519-6612. 23 p. + appendices.

CRONIN, M.A., BALLARD, W.B., BRYAN, J.D., PIERSON, B.J., and McKENDRICK, J.D. 1998. Northern Alaska oil fields and caribou: A commentary. Biological Conservation 83:195208.

CRONIN, M.A., PIERSON, B.J., JOHNSON, S.R., NOEL, L.E., and BALLARD, W.B. 1997. Caribou population density in the Prudhoe Bay region of Alaska. The Journal of Wildlife Research 2:59-68.

DAU, J.R., and CAMERON, R.D. 1986. Effects of a road system on caribou distribution during calving. Rangifer 1:95-101.

LEBRETON, J.-D., BURNHAM, K., CLOBERT, P.J., and ANDERSON, D.R. 1992. Modeling survival and testing biological hypotheses using marked animals: A unified approach with case studies. Ecological Monographs 62:67-118.

MAKI, A.W. 1992. Of measured risks: The environmental impacts of the Prudhoe Bay, Alaska, oil field. Environmental Toxicology and Chemistry 12:1691-1707.

MANLY, B.F.J. 1994. The design and analysis of research studies. Cambridge: Cambridge University Press. 353 p.

MANLY, B.F.J., McDONALD, L., and THOMAS, D. 1993. Resource selection by animals. London: Chapman and Hall. $177 \mathrm{p}$.

NELLEMANN, C., and CAMERON, R.D. 1996. Effects of petroleum development on terrain preferences of calving caribou. Arctic 49:23-28.

NETER, J., WASSERMAN, W., and KUTNER, M.H. 1990. Applied linear statistical models. 3rd ed. Burr Ridge, Illinois: Irwin Press. $1181 \mathrm{p}$.

NEU, C.W., BYERS, C.R., and PEEK, J.M. 1974. A technique for analysis of utilization-availability data. Journal of Wildlife Management 38:541-545.

POLLARD, R.H., and BALLARD, W.B. 1993. Caribou distribution in the Prudhoe Bay oil field, summer 1992. Final report prepared by LGL Alaska Research Associates, Inc., for BP Exploration (Alaska) Inc., P.O. Box 196612, Anchorage, Alaska 995196612. 24 p. + maps.

POLLARD, R.H., and NOEL, L.E. 1994. Caribou distribution and parasitic insect abundance in the Prudhoe Bay oil field, summer 1993. Final report prepared by LGL Alaska Research Associates, Inc., for BP Exploration (Alaska) Inc., P.O. Box 196612, Anchorage, Alaska 99519-6612. 65 p. + maps.
1995. Caribou distribution in the Prudhoe Bay oil field, summer 1994. Final report prepared by LGL Alaska Research Associates, Inc., for BP Exploration (Alaska) Inc., P.O. Box 196612, Anchorage, Alaska 99519-6612. 15 p. + maps.

1996. Caribou distribution in the Prudhoe Bay oil field, summer 1995. Draft report prepared by LGL Alaska Research Associates, Inc., for BP Exploration (Alaska) Inc., P.O. Box 196612, Anchorage, Alaska 99519-6612. 13 p. + maps.

POLLARD, R.H., MILLER, M.E., and WILKINSON, R.C. 1992a. Caribou distribution in the Prudhoe Bay oil field, summer 1990. Final report prepared by LGL Alaska Research Associates, Inc., for BP Exploration (Alaska) Inc., P.O. Box 196612, Anchorage, Alaska 99519-6612. 41 p. + maps.

POLLARD, R.H., LENT, P.E., MILLER, M.E., and WILKINSON, R.C. 1992b. Caribou distribution in the Prudhoe Bay, Kuparuk, and Milne Point oil fields, summer 1991. Final report prepared by LGL Alaska Research Associates, Inc., Anchorage, Alaska for BP Exploration (Alaska) Inc., Anchorage, Alaska. 25 p. + maps.

POLLARD, R.H., BALLARD, W.B., NOEL, L.E., and CRONIN, M.A. 1996a. Summer distribution of caribou in relation to the Prudhoe Bay oil field, Alaska, 1990-1994. Canadian FieldNaturalist 110:659-674.

- 1996b. Parasitic insect abundance and microclimate of gravel pads and tundra within the Prudhoe Bay oil field, Alaska in relation to use by caribou. Canadian Field-Naturalist 110: $649-658$.

SMITH, W.T., and CAMERON, R.D. 1990. Habitat requirements and potential impacts of oil development on caribou. In: Cameron, R.D., Smith, W.T., and Whitten, K.R., eds. Distribution and productivity of the Central Arctic caribou herd in relation to petroleum development. Federal Aid in Wildlife Restoration Projects W-23-2 and W-23-3. Juneau, Alaska: Alaska Department of Fish and Game.

VAN DYKE, F., and KLEIN, W.C. 1996. Response of elk to installation of oil wells. Journal of Mammalogy 77:1028-1041.

WALKER, D.A., EVERETT, K.R., WEBBER, P.J., and BROWN, J. 1980. Geobotanical atlas of the Prudhoe Bay Region, Alaska. U.S. Army Corps of Engineers, CRREL Report 80-14. Hanover, New Hampshire: Cold Regions Research and Engineering Laboratory. 